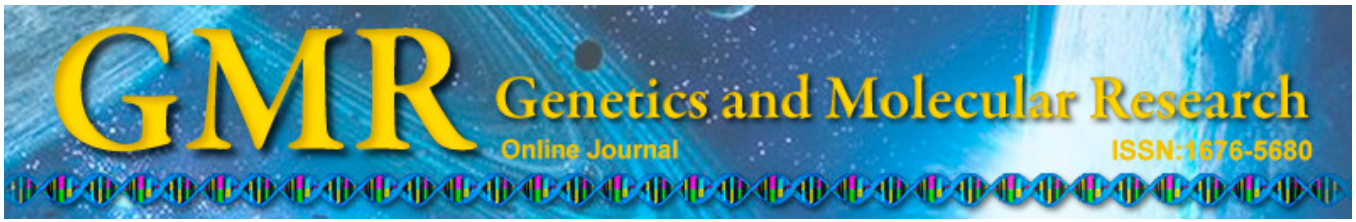

\title{
Biotechnological prospecting of foliar endophytic fungi of guaco (Mikania glomerata Spreng.) with antibacterial and antagonistic activity against phytopathogens
}

J.C. Polonio ${ }^{1}$, T.T. Almeida ${ }^{1}$, A. Garcia ${ }^{1}$, G.E.G. Mariucci², J.L. Azevedo ${ }^{3}$, S.A. Rhoden ${ }^{1}$ and J.A. Pamphile ${ }^{1}$

${ }^{1}$ Departamento de Biotecnologia, Genética e Biologia Celular, Universidade Estadual de Maringá, Maringá, PR, Brasil

${ }^{2}$ Departamento de Agronomia, Universidade Estadual de Maringá, Maringá, PR, Brasil

${ }^{3}$ Departamento de Genética, Escola Superior de Agricultura Luiz de Queiroz, Universidade de São Paulo, Piracicaba, SP, Brasil

Corresponding author: J.A. Pamphile

E-mail: prof.pamphile@gmail.com / japamphile@uem.br

Genet. Mol. Res. 14 (3): 7297-7309 (2015)

Received October 21, 2014

Accepted February 19, 2015

Published July 3, 2015

DOI http://dx.doi.org/10.4238/2015.July.3.5

\begin{abstract}
Mikania glomerata (Spreng.), popularly known as "guaco", is a plant from the Asteraceae family that has many therapeutic properties. The use of medicinal plants has been examined in studies on endophytic diversity and bioprospecting; endophytes inhabit the interior of plants without harming them. Microorganism-host complex interactions are related to the production of compounds that may confer resistance to pathogens or to production of bioactive compounds or growth regulators. In this study, we evaluated foliar endophytic fungi of M. glomerata to examine the control of plant pathogens, molecular identification, and production of compounds with antimicrobial activity. In the antagonism test, 6-mm diameter disks were placed equidistant
\end{abstract}


from the endophyte and plant pathogen, and pathogen growth area was measured. The endophytic strains G-01, G-02, and G-03 were effective against Fusarium solani and Didymella bryoniae. The endophyte rDNA regions corresponding to internal transcribed spacer 1-5.8S-internal transcribed spacer 2 were sequenced, and the results were compared with sequences deposited in the NCBI database. The G-01, G-02, and G-03 strains were identified as Diaporthe citri. This identification was confirmed by phylogenetic analysis. The crude extract of the secondary metabolites of the G-01 strain was tested against Escherichia coli and Staphylococcus aureus; the metabolites showed antimicrobial activity against $S$. aureus. The endophytes tested in this study have potential for use in biotechnological applications.

Key words: Bioactive compounds; DNA barcode; Fungal ethyl acetate extracts; Microbial biotechnology

\section{INTRODUCTION}

Mikania glomerata (Spreng.), commonly known as "guaco", is a native climbing plant from Brazil that belongs to the Asteraceae family and is popularly used to treat asthma and bronchitis and as an adjuvant for cough treating. It also has anti-allergic, antimicrobial, analgesic, anti-inflammatory, antioxidant, and anti-diarrheal activities (Ruppelt et al., 1991; Fierro et al., 1999; Pessini et al., 2003; Falcão et al., 2005; Salgado et al., 2005; Vicentino e Menezes, 2007). In 1929, M. glomerata was included in the Brazilian Pharmacopoeia, 1st edition. Because of its therapeutic properties, its syrup and oral solution were included in the medicine reference list and complementary supplies for pharmaceutical services in basic health care. Therefore, guaco-based herbal medicines are used extensively in the public health system, through the implementation of herbal medicine programs in several cities in Brazilian states (Gasparetto et al., 2010). The traditional use of plants with medicinal properties has promoted studies on the diversity and bioprospecting of endophytic fungi and bacteria.

The presence of endophytic microorganisms in medicinal plants has been observed in numerous species (Bernardi-Wenzel et al., 2010; Garcia et al., 2012a; Orlandelli et al., 2012; Rhoden et al., 2013); these organisms are often involved in complex relationships between the synthesis, degradation and accumulation of secondary metabolites of biotechnological interest. In many cases, an important symbiotic interaction exists with the host plant, involving the production of compounds that can reduce herbivory on plant tissues, confer resistance to plant pathogens, and produce plant growth regulators to increase plant development (Azevedo et al., 2000).

Endophytic microorganisms are those that inhabit the interior of plants during at least 1 period of the plant life cycle (Azevedo et al., 2000); they may colonize the inter- and intracellular plant spaces (Bernardi-Wenzel et al., 2010; Garcia et al., 2012a). These organisms do not harm the plants, but rather exhibit an asymptomatic relationship (Pamphile and Azevedo, 2002).

The endophytic fungus Taxomyces andreanae isolated from Taxus brevifolia Nutt. (Taxaceae), tested by Stierle et al. (1993), was shown to produce Taxol, a diterpenoid complex used to treat various types of cancer, such as endometrial tumors and breast cancer. The discovery is of great biotechnological and also of ecological importance, as the only source of Taxol until then was from the plant's peels. Peels from more than 1000 trees, each more than 
100 years old, were required to obtain $1 \mathrm{~kg}$ Taxol, which nearly led to the extinction of the species (Stinson et al., 2003).

Based on the data from the Environment Ministry of Brazil in 2002, Rhoden et al. (2013) stand out that Brazil has the richest flora in the world, with more than 56,000 species of plants. In all the plant species studied, at least 1 endophytic fungus has been described.

Studies of endophytic biodiversity have focused on internal transcribed spacer 1 (ITS1)-5.8S-ITS2 sequencing to identify endophytic fungi (Bernardi-Wenzel et al., 2010; Garcia et al., 2012a; Orlandelli et al., 2012; Rhoden et al., 2013). ITS regions are flanked by conserved segments (genes $18 \mathrm{~S}, 5.8 \mathrm{~S}$, and $28 \mathrm{~S}$ ), which provide information about phylogenetic and taxonomic levels. ITS regions are subject to a high mutation rate during the evolution process, which can be examined for intraspecific classification.

The use of endophytic microorganisms as a source of bioactive compounds or as secondary metabolites is an interesting strategy, as these microorganisms inhabit the interior of plants without causing apparent symptoms of illness; growth in this environment involves continuous metabolic interaction between the endophyte and the host (Lacava et al., 2010). As the endophytes are directly related to the host plants, Schulz et al. (2002) suggested that these microorganisms are excellent sources of secondary metabolites. Garcia et al. (2012a) isolated 102 endophytic fungus lineages in leaf fragments of the medicinal plant Sapindus saponaria L. (Sapindales: Sapindaceae), and found that metabolic extracts had antibacterial activities against the pathogenic bacteria Escherichia coli, Staphylococcus aureus, Salmonella typhi, Micrococcus luteus, and Enterococcus hirae (Garcia et al. 2012b).

In this study, we evaluated endophytic fungi from $M$. glomerata leaves to examine its in vitro biotechnological potential for controlling pathogenic fungi. We also conducted molecular identification of endophytes with high antagonist activity to assess the potential of the compounds regarding their antibacterial activities.

\section{MATERIAL AND METHODS}

\section{Microbial strains}

The microorganism strains used in this study were from the collection at the Laboratory of Microbial Biotechnology, State University of Maringá - UEM, Maringá, State of Paraná, Brazil. Forty endophytic fungi were isolated from the leaves of $M$. glomerata collected in the UEM-Educational Garden ( $23^{\circ} 24^{\prime} 14^{\prime \prime}$ S, 51 $\left.1^{\circ} 56^{\prime} 19^{\prime \prime} \mathrm{W}\right)$ in March 2013 using the fragmentation method as described by Araújo et al. (2010).

\section{In vitro antagonist activity of endophytic fungi}

To test the antimicrobial activity against pathogenic fungi (Fusarium solani and Didymella bryoniae), 40 foliar endophytic fungi from $M$. glomerata were tested. This test was conducted using the paired culture technique as described by Campanile et al. (2007), with modifications.

Disks (6 $\mathrm{mm}$ in diameter) with colonies of endophytic and pathogen isolates were inoculated at opposite poles of Petri dishes containing potato dextrose agar culture medium, at a distance of $4 \mathrm{~cm}$ from each other. Tests were performed in triplicate, along with negative 
controls, where was inoculated the pathogen in only one point (control C1) and in two poles (control C2) at a distance equal from treatments.

The competitive interactions between endophytes and pathogens under in vitro conditions were analyzed according to the scale proposed by Badalyan et al. (2002), based on 3 types of interactions: $\mathrm{A}, \mathrm{B}$, and $\mathrm{C}$, where $\mathrm{C}$ is divided into 4 sub-categories (CA1, CA2, CB1, and $\mathrm{CB} 2$ ), with $\mathrm{A}=$ blocking mycelial growth with contact, $\mathrm{B}=$ blocking distance, $\mathrm{C}=$ endophytic growth on the initial pathogen without blocking; $\mathrm{CA} 1$ and $\mathrm{CA} 2=$ partial and complete endophyte growth on the pathogen after initial blocking with mycelial contact, and CB1 and $\mathrm{CB} 2$ = partial and complete endophyte growth on the pathogen after initial distance blocking. The inhibition index was evaluated using the ImageJ software (v. 1.46r); Petri dishes were photographed and assessed for pathogen area and the results were then compared to those for the control. Inhibition index percentage was calculated as follows: $\operatorname{Im} \%=(1-\mathrm{MT} / \mathrm{MC}) \mathrm{x}$ 100 , where $\mathrm{Im} \%$ = inhibition index percentage of mycelial growth, $\mathrm{MT}=$ mean of triplicate area measured for treatment in $\mathrm{cm}^{2}$, and $\mathrm{MC}=$ average of triplicate control area in $\mathrm{cm}^{2}$.

$\mathrm{Im} \%$ values were statistically evaluated using analysis of variance and the means were compared using the Scott-Knott test $(\mathrm{P}<0.05)$ with the statistical program Sisvar 5.3 (Ferreira, 2011).

\section{Molecular identification of endophytic fungi based on sequencing of ITS1-5.8S- ITS2 region}

For the molecular identification of strains G-01, G-02, and G-03, DNA was extracted using the PowerSoil ${ }^{\circledR}$ DNA Isolation Kit (MO BIO Laboratories, Inc., Carlsbad, CA, USA) following manufacturer instructions. Amplification of the region of ribosomal DNA, ITS15.8S-ITS2, was performed using the primers ITS1 (5'-TCCGTAGGTGAACCTGCGG-3') and ITS4 (5'-TCCCCGCTTATTGATATGC-3'), as described by White et al. (1990), with initial denaturation at $92^{\circ} \mathrm{C}$ for $4 \mathrm{~min}$; followed by 35 cycles of denaturation at $92^{\circ} \mathrm{C}$ for $40 \mathrm{~s}$, annealing at $52^{\circ} \mathrm{C}$ for $1 \mathrm{~min}$ and $30 \mathrm{~s}$, and extension at $72^{\circ} \mathrm{C}$ for $2 \mathrm{~min}$; followed by a final extension at $72^{\circ} \mathrm{C}$ for $5 \mathrm{~min}$. Negative controls containing all reagents except genomic DNA were prepared for each polymerase chain reaction (PCR). The amplified regions of the isolates were purified using the GFX PCR DNA kit and Gel Band Purification kit (Amersham Biosciences, Amersham, UK). The extracted DNA was then subjected to quantification on a $1 \%$ agarose gel and photographed.

PCR products were sequenced using the ABI-PRISM 3100 Genetic Analyzer equipment (Applied Biosystems). Samples for sequencing were prepared in microcentrifuge tubes in a volume of 0.5 mL, containing 30-60 ng DNA samples, 4.5 pmol primer ITS1, and $6 \mu \mathrm{L}$ Milli-Q water.

For isolate identification, nucleotide sequences were compared with those deposited in the NCBI database. Identification was determined based on the best identity value obtained and the sequences were deposited in the NCBI database.

\section{Phylogenetic analysis}

The sequences were aligned using the MEGA software version 6.05 using the "neighbor-joining" method with "p-distance" for nucleotides with "the pairwise gap deletion" option and bootstrap with 10,000 replications to construct the phylogenetic tree. We also used 
sequences with greater similarity from NCBI and another 3 genetically distant sequences used as external groups to force the alignment. Evolutionary distance was analyzed using the Jukes and Cantor method (Saitou and Nei, 1987). To ensure that the actual evolutionary distance between organisms is not underestimated, the program applies a specific evolutionary model, with correction for multiple substitutions.

Based on the distance matrix, the topology of the phylogenetic tree was reconstructed using the neighbor-joining method. This method is based on a topology without resolution and search, at each cycle, and the pair of sequences contributing the smallest number of branches to the tree topology (minimum evolution method).

\section{Metabolic extract obtainment}

Isolated G-01, which presented a higher inhibition index in the paired culture tests, was selected to obtain secondary metabolites. The fungus was grown on potato dextrose broth, based on the method of Rukachaisirikul et al. (2008), with modifications. We inoculated 2-3 discs $(6 \mathrm{~mm}$ in diameter) into 2 Erlenmeyer flasks containing $1 \mathrm{~L}$ broth. The samples were incubated under stationary conditions in a biochemical oxygen demand incubator for 21 days at $28^{\circ} \mathrm{C}$. Next, the fungus was filtered through cheesecloth and the medium was centrifuged for $15 \mathrm{~min}$ at $3600 \mathrm{~g}$.

The liquid-liquid extraction of the supernatant to obtain the crude extract was performed using ethyl acetate in a ratio of 1:5 (ethyl acetate:fermented medium) and a separation funnel. This step was repeated 4 times. The solvent present in the separatory funnel was collected and evaporated using a rotary evaporator (MA 120, Marconi, São Paulo, Brazil) at $40^{\circ} \mathrm{C}$, resulting in the concentration of the metabolic extract.

\section{Evaluation of antibacterial activity}

The antibacterial activity of the metabolite extract was tested in 2 bacterial strains: $E$. coli (ATCC 25922) and S. aureus (ATCC 25923). The bacteria were grown for $24 \mathrm{~h}$ in trypticase soy broth medium, and then adjusted to a concentration of $1.5 \times 10^{8}$ colony-forming units/ $\mathrm{mL}$ using the McFarland 0.5 scale. Bacteria $(100 \mu \mathrm{L})$ were seeded on Petri dishes containing trypticase soy agar medium, performing scattering with a Drigalsky's handle. We next inserted 6 filter discs of sterile Whatman No. $4(\varnothing 6 \mathrm{~mm})$ at equal distances on each plate, embedded in $10 \mu \mathrm{L}$ fungal extract previously diluted in methanol $(\mathrm{MeOH})$ at concentrations of $0,10,15$, 20,30 , and $50 \mathrm{mg} / \mathrm{mL} \mathrm{MeOH}$. For the control, tetracycline was inoculated at a concentration of $4 \mathrm{mg} / \mathrm{mL}$ in $\mathrm{MeOH}$. The dishes were incubated at $37^{\circ} \mathrm{C}$ for $24 \mathrm{~h}$. Formation of an inhibition zone, which indicated activity, was assessed by measuring the halos distance from the edge of the disc filter paper to the edge of the halos formed; these values were compared to those for the control with tetracycline. The gradual increase in the halos was evaluated using the Tukey test $(\mathrm{P}<0.05)$ and linear regression analysis.

\section{RESULTS}

\section{Antagonistic activity of endophytic fungi isolated from M. glomerata}

To examine the use of isolated endophytes from M. glomerata for controlling plant 
pathogens, we used the paired culture test and observed 3 types of interactions between leaf endophytes of $M$. glomerata and the pathogens tested, including A, B, and CA1, as described by Badalyan et al. (2002). Most showed the type A interaction (above $90 \%$ of strains), which is characterized by mycelial contact and physical interaction between fungi. Table 1 shows the variability of the interaction types between endophytic and plant pathogenic strains.

Table 1. Competitive interaction of endophytic fungi from the plant pathogens tested according to the scale described by Badalyan et al. (2002).

\begin{tabular}{lcr}
\hline Phytopathogen & Competitive interaction & Percentage of isolates (\%) \\
\hline Fusarium solani & A & 97.5 \\
Didymella bryoniae & B & 2.5 \\
& A & 92.5 \\
& B & 5.0 \\
\end{tabular}

For the Im\% calculation, the growth area of the $\mathrm{C} 2$ control was considered. How the test between pathogen versus the same pathogen strain should not result in a competitive interaction between the two, its $\operatorname{Im} \%=0 \%$.

According to statistical analysis, only 1 group of the 3 fungal strains, corresponding to $7.5 \%$ of the fungi, showed the highest Im\% (Table 2). The corresponding lineages were G- 01 , G-02, and G- 03 , presenting Im $\%$ average values of $60 \%$ against $F$. solani (Figure 1 ) and $66 \%$ against $D$. bryoniae (Figure 2). Additional strains showing $\operatorname{Im} \%$ values that were significantly different from controls against phytopathogen $D$. bryoniae showed $17.8 \%$ inhibition on average, representing $55 \%$ of the tested fungi.

Table 2. Average of pathogen mycelial growth and the average percentage of inhibition (Im\%) of statistical groups defined using the Skott-Knott test.

\begin{tabular}{|c|c|c|c|c|}
\hline Phytopathogen & $\begin{array}{l}{ }^{1} \text { Average of the pathogen growth }\left(\mathrm{cm}^{2}\right) \\
\text { by statistical group (standard error) }\end{array}$ & $\begin{array}{l}\text { Average of } \operatorname{Im} \% \\
\text { compared to } \mathrm{C} 2\end{array}$ & $\begin{array}{l}\text { Percentage } \\
\text { of isolates }\end{array}$ & Lineages \\
\hline \multirow[t]{5}{*}{ Didymella bryoniae } & $3.88^{\mathrm{a}}(0.53)$ & $66.04 \%$ & $7.5 \%$ & G-01, G-02, G-03 \\
\hline & $9.28^{\mathrm{b}}(0.53)$ & $17.82 \%$ & $55.0 \%$ & $\begin{array}{l}\text { G-13, G-37, G-06, G-22, G-05, G-19, } \\
\text { G-39, G-17, G-25, G-24, G-26, G-08, } \\
\text { G-15, G-04, G-09, G-21, G-40, G-30, } \\
\text { G-27, G-16, G-23, G-31 }\end{array}$ \\
\hline & $10.91^{\mathrm{c}}(0.53)$ & $4.41 \%$ & $37.5 \%$ & $\begin{array}{l}\text { G-38, G-33, G-18, G-07, G-10, G-14, } \\
\text { G-12, G-34, G-11, G-35, G-20, G-29, } \\
\text { G-36, G-28, G-32 }\end{array}$ \\
\hline & $12.33^{\mathrm{c}}(0.53)$ & - & - & Control C1 \\
\hline & $11.41^{\mathrm{c}}(0.53)$ & - & - & Control C2 \\
\hline \multirow[t]{6}{*}{ Fusarium solani } & $10.97^{\mathrm{a}}(1.17)$ & $60.13 \%$ & $7.5 \%$ & G-01, G-02, G-03 \\
\hline & $20.13^{\mathrm{b}}(1.17)$ & $25.51 \%$ & $27.5 \%$ & $\begin{array}{l}\text { G-05, G-37, G-24, G-15, G-13, G-38, } \\
\text { G-39, G-18, G-31, G-40, G-19 }\end{array}$ \\
\hline & $24.50^{\mathrm{c}}(1.17)$ & $9.70 \%$ & $45.0 \%$ & $\begin{array}{l}\text { G-12, G-07, G-06, G-04, G-27, G-32, } \\
\text { G-30, G-25, G-22, G-36, G-14, G-08, } \\
\text { G-09, G-11, G-10, G-23, G-35, G-28, } \\
\text { G-21, G-26 }\end{array}$ \\
\hline & $28.28^{\mathrm{d}}(1.17)$ & $-2.25 \%$ & $20.0 \%$ & G-34, G-33, G-16, G-20, G-29, G-17 \\
\hline & $34.81^{\mathrm{e}}(1.17)$ & - & - & Control C1 \\
\hline & $27.52^{\mathrm{d}}(1.17)$ & - & - & Control C2 \\
\hline
\end{tabular}

${ }^{1}$ Average of mycelial pathogen growth followed by the statistical group where the means did not differ according to the Skott-Knott test, for the nominal value of $5 \%$ significance. 


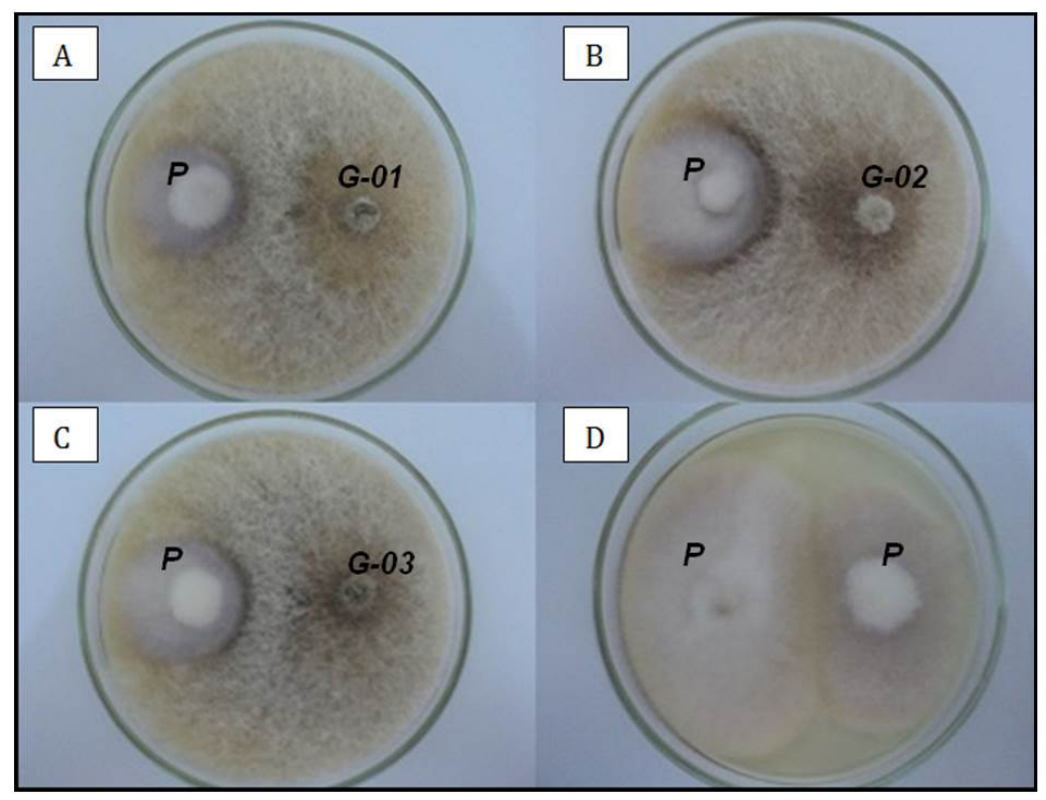

Figure 1. Test of antagonism of endophytic fungi against the pathogen Fusarium solani, indicating the endophytic lineages (G-01, G-02, and G-03) and the pathogen (P). A. Endophytic G-01 against $F$. solani. B. Endophytic G-02 against $F$. solani. C. Endophytic G-03 against $F$. solani. D. Control C2.

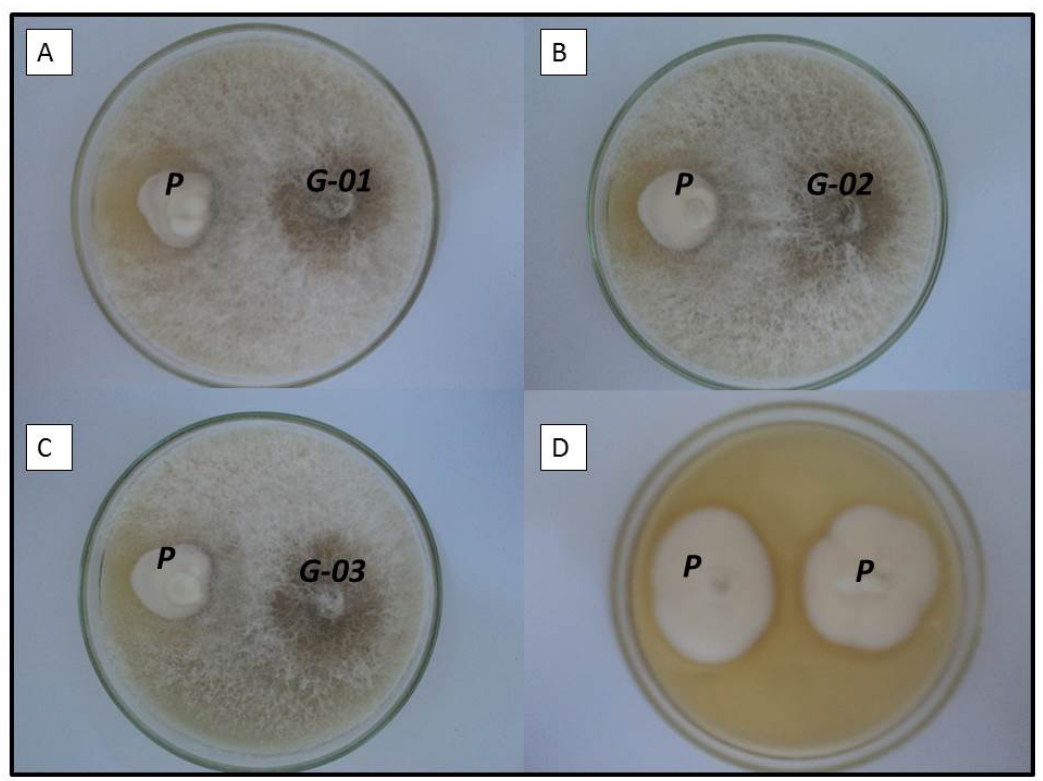

Figure 2. Test of antagonism of endophytic fungi against the pathogen Didymella bryoniae, indicating the endophytic lineages (G-01, G-02, and G-03) and the pathogen (P). A. Endophytic G-01 against D. bryoniae. B. Endophytic G-02 against D. bryoniae. C. Endophytic G-03 against D. bryoniae. D. Control C2. 
Against $F$. solani, 2 other groups presented significant inhibition values, and the statistical group "b" with an average Im\% of $25.5 \%$, represented by $27.5 \%$ of endophytes and "c" with average Im\% values of 9 and $7 \%$, by $45 \%$ of endophytes. The other fungi showed no significant differences compared with controls.

\section{Molecular identification and phylogenetic analysis}

ITS1-5.8S-ITS2 sequence analysis using BLAST (http://blast.ncbi.nlm.nih.gov/Blast.cgi) in the NCBI database revealed that the strains G-01, G- 02 , and G-03 corresponded to the species Diaporthe citri (Table 3), with the higher indices of similarity as 95,97 , and $99 \%$, respectively.

Table 3. Molecular identification of endophytic lineages.

\begin{tabular}{llcc}
\hline Endophytic lineage & Fungus with highest similarity & Accession No. on the NCBI & Identity (\%) \\
\hline G-01 & Diaporthe citri & KC343051.1 & 95.0 \\
G-02 & Diaporthe citri & KC343051.1 & 97.0 \\
G-03 & Diaporthe citri & KC343051.1 & 99.0 \\
\hline
\end{tabular}

Phylogenetic analysis (Figure 3 ) confirmed the high similarity between the G-01 and G-02 strains, with $100 \%$ of bootstrap and $68 \%$ compared to G-03 (G-01, G-02, and G-03 in the NCBI database corresponded to KJ934221, KJ9342219, and KJ934220, respectively). These strains joined in a clade with other isolates of D. citri (KC343051.1, KC343052.1, and KC343053.1), showing $54 \%$ of bootstrap. These results support the identification of these endophytes as $D$. citri.

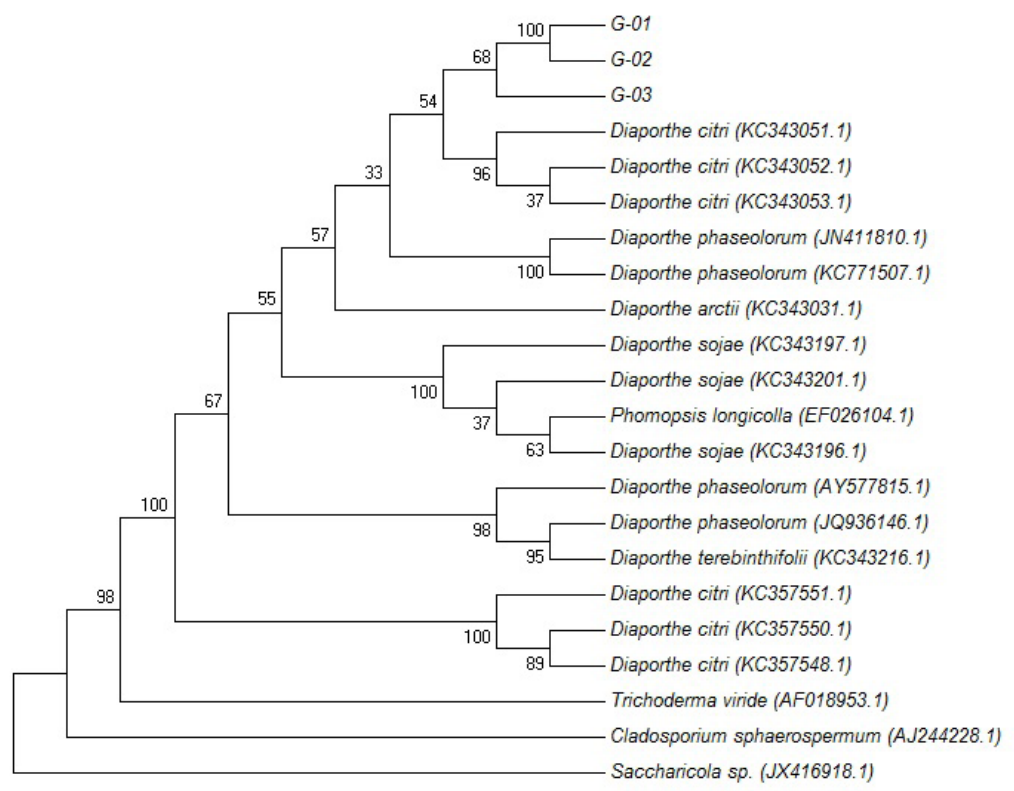

Figure 3. Phylogenetic tree of foliar endophytic fungi of Mikania glomerata with other fungi obtained from the GenBank database, constructed using the neighbor-joining method using p-distance for nucleotides with the pairwise gap deletion. The numbers on the tree indicate the percentage of times the group on the right occurred on the same node during consensus evaluation (bootstrap with 10,000 replications). 


\section{Evaluation of antimicrobial activity of metabolic extract}

From an initial volume of $2 \mathrm{~L}$ potato dextrose culture medium, $151.3 \mathrm{mg}$ isolate $\mathrm{G}-01$ was extracted (D. citri) (yield $75.65 \mathrm{mg} / \mathrm{L}$ medium) and was a dark caramel color. After 21 days of incubation, the remaining $1.4 \mathrm{~L}$ medium was used for metabolite extraction.

The antibacterial test using crude extract of secondary metabolites was diluted in $\mathrm{MeOH}$ and tested against $S$. aureus. This extract showed significant efficiency compared with the control with $\mathrm{MeOH}$ at a concentration of $30 \mathrm{mg} / \mathrm{mL}$, and the formation of inhibition halos was observed. In contrast, it was not observed the formation of halos for the crude extracts against the bacterium E. coli (Figure 4 and Table 4).

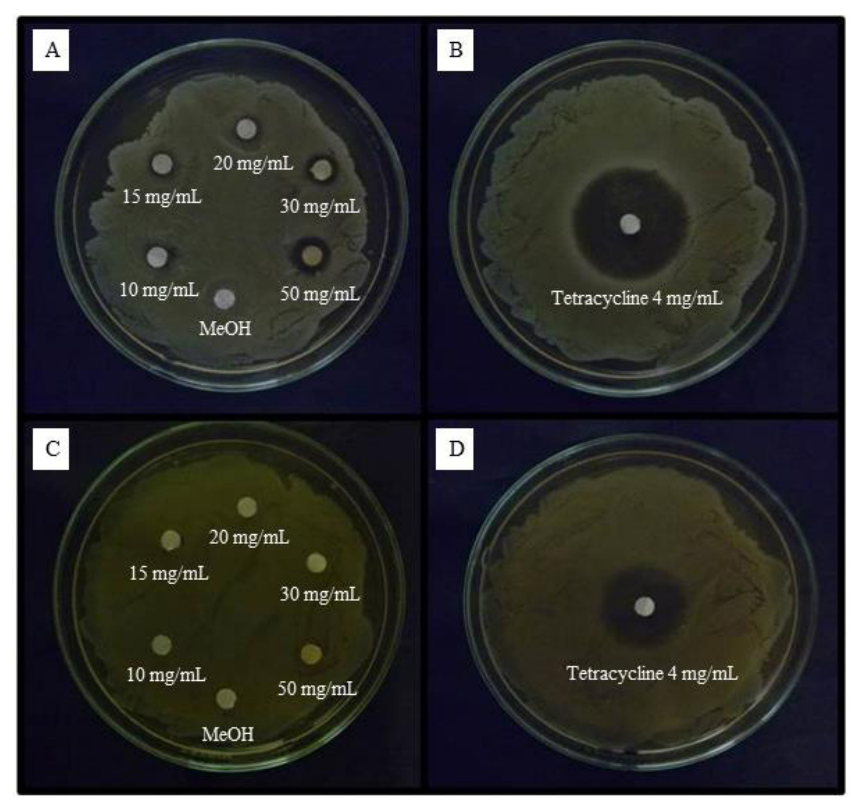

Figure 4. Diffusion test with disk with crude extract of secondary metabolites of the G-01 endophyte (Diaporthe citri); (A) Staphylococcus aureus; (B) S. aureus with $4 \mathrm{mg} / \mathrm{mL}$ tetracycline in $\mathrm{MeOH}$; (C) Escherichia coli; (D) E. coli with $4 \mathrm{mg} / \mathrm{mL}$ tetracycline diluted in methanol.

Table 4. Evaluation of the antimicrobial activity of the Diaporthe citri (G-01) metabolic extract based on the
formation of inhibition halos measured in mm, analyzed using the Tukey statistical test.
\begin{tabular}{lcc}
\hline Tratments & Pathogenic bacteria \\
\cline { 2 - 3 } & ${ }^{1}$ Staphylococcus aureus & ${ }^{2}$ Escherichia coli \\
\hline $10 \mathrm{mg} / \mathrm{mL}$ & $0.3^{\text {ab }}(0.29)$ & 0.00 \\
$15 \mathrm{mg} / \mathrm{mL}$ & $0.3^{\text {ab }}(0.29)$ & 0.00 \\
$20 \mathrm{mg} / \mathrm{mL}$ & $1.2^{\text {bbc }}(0.29)$ & 0.00 \\
$30 \mathrm{mg} / \mathrm{mL}$ & $1.5^{\mathrm{bc}}(0.29)$ & 0.00 \\
$50 \mathrm{mg} / \mathrm{mL}$ & $2.3^{\mathrm{c}}(0.29)$ & 0.00 \\
Control with methanol & $0.0^{\mathrm{a}}(0.29)$ & 0.00 \\
Control with tetracycline $(4 \mathrm{mg} / \mathrm{mL}$ methanol $)$ & $11.7^{\mathrm{d}}(0.29)$ & 8.00
\end{tabular}

${ }^{1}$ Average of the inhibition halos followed the statistical group obtained by the Tukey test for the nominal value of $5 \%$ significance level, and standard error in parentheses. ${ }^{2}$ No inhibition halos formed. 
The results obtained in the present study were not significant compared to the control with tetracycline, but inhibition of $S$. aureus increased with increasing concentrations of the metabolic extract (Figure 5).

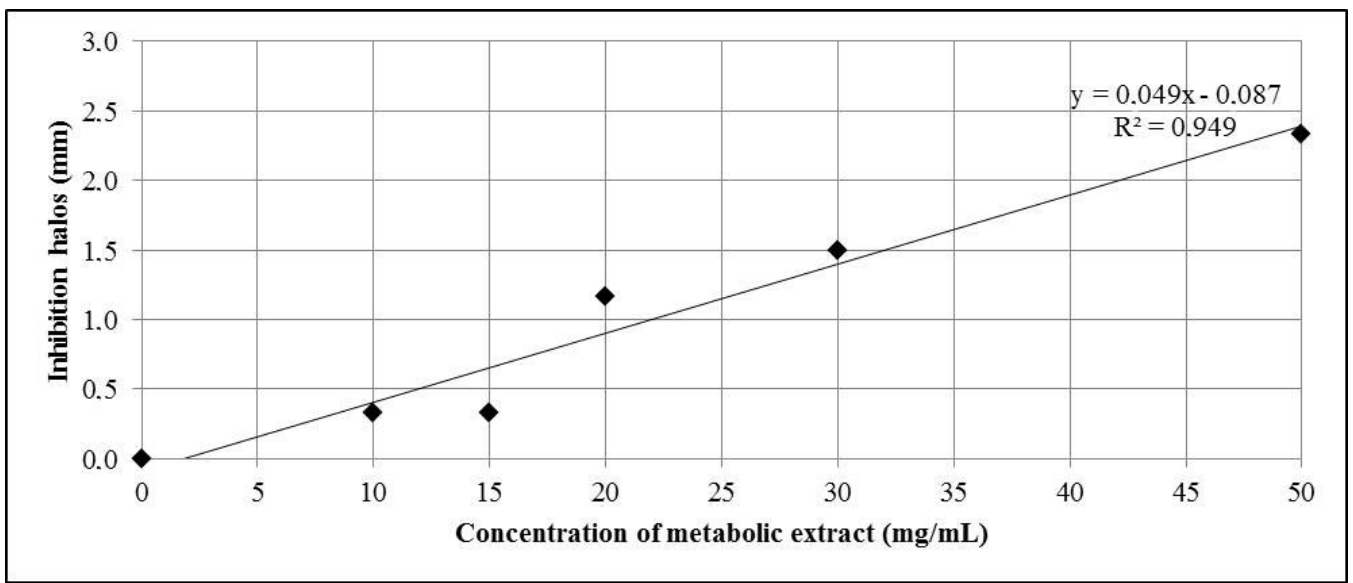

Figure 5. Regression analysis of the inhibition of halo formation test with the metabolic extract from the endophytic fungus Diaporthe citri (G-01) against Staphylococcus aureus.

\section{DISCUSSION}

The biological control aims to maintain a balance in agrosystems, so that the host, in the pathogen presence, could suffer less damage due to the controlling action of non-pathogenic microorganisms that inhibit/antagonize the pathogens of plants. As demonstrated by Azevedo et al. (2000), endophytic microorganisms have gained interest for use in biological control, where it is necessary to develop viable alternatives for reducing the use of chemicals, such as fungicides and pesticides, as well as the recurrent problems of their indiscriminate use. Complex interactions between the plant and beneficial microbiota make the use of chemical controllers difficult, because its use can be detrimental to beneficial microorganisms, besides having negative environmental effects (Ethur et al., 2007).

Different modes of action of endophytes over the plant pathogens may have occurred, and this initial evaluation indicates a potential for the production of metabolic compounds that inhibit pathogen growth or the direct competition for nutrients and space, simulating the situation within the plant host (Bernardi-Wenzel et al., 2012).

Endophytic microorganisms, showing the best inhibition indices ( $\operatorname{Im} \%)$ were considered candidates for tests involving production of secondary metabolites with potential antimicrobial activity.

Mejía et al. (2008) showed that, in endophytic fungi isolated from healthy tissues of cocoa (Theobroma cacao L.), 65\% of isolates presented antagonism against Phytophthora palmivora, 40\% against Moniliophthora roreri, and 27\% against Moniliophthora perniciosa. For endophytes of soybean [Glycine max (L.) Merrill], Bernardi-Wenzel et al. (2012), using a similar methodology, observed $78 \%$ inhibition against Alternaria solani, $47 \%$ against $F$. so- 
lani, and $67 \%$ against Rhizoctonia solani. These and other studies using endophytic microorganisms, demonstrated their biotechnological potential for future applications in the biological control of plant pathogens in important cultivars (Campanile et al., 2007; Dolatabadi et al., 2012; Núñez-Trujillo et al., 2012; Kusari et al., 2013).

Application of endophytic microorganisms for the biological control of microbial pathogens and insect pests has shown promising results; however, methods must be developed for effective application in the field. The interference of external factors, such as climate conditions in different regions, interactions with other plants and microbial species, the microorganisms' modes of action, the amount of endophytics that should be applied, and the entry method and interaction with the plant host, are factors that currently limit the application of endophytic microorganisms for biological control. Further studies are needed to resolve these limitations.

The endophytes G-01, G-02, and G-03, which have similar morphological characteristics, as shown in Figures 1 and 2, presented promising results in the antagonism test and were subjected to molecular identification by sequencing of the ITS1-5.8S-ITS2. They were assigned as D. citri. Using in silico analysis, Rhoden et al. (2013) analyzed the ITS1-5.8SITS2 sequences identified using the GenBank database of NCBI of endophytic fungi isolated from 73 plant species. A large phylogenetic tree was constructed using the MEGA 5 software, highlighting the robustness of GenBank for use in studies in which it is necessary for molecular identification of endophytic community in terms of the genus, showing $98 \%$ consistency with the deposited sequences.

The fungus $D$. citri, which imperfectly corresponded to Phomopsis citri, is usually related as the causal agent of melanosis and peduncular rot of citrus cultivars. Melanosis is important in orchards for which production is destined for the fresh fruit market, as the disease affects the fruit's external appearance and is more severe in old and mismanaged orchards (Kimati et al., 1997).

Endophytic fungi grow asymptomatically inside their hosts. Colonization of the endophyte-pathogen depends not only on the adaptations to their particular host or even organ and stage of development of the fungus-plant, but also in the innate host defense mechanism and variation in virulence of the endophyte, as well as on environmental conditions (Schulz and Boyle, 2005).

Important antifungal and antibacterial compounds can be obtained from microbial metabolites or their semisynthetic derivatives. Recent studies have identified different chemical compounds obtained from endophytes with antimicrobial activities, such as alkaloids, phenols, quinones, and terpenes (Strobel et al., 1999; Silva et al., 2006; Aly et al., 2008), indicating biotechnological potential for obtaining new natural products. Yu et al. (2009) noted that $35 \%$ of compounds with antimicrobial activity from endophytic microorganisms were obtained from fungi isolated from medicinal plants.

Specian et al. (2012) examined a foliar endophytic strain of Diaporthe helianthi isolated from Luehea divaricata using column chromatography and nuclear magnetic resonance analyses. They identified the compound 2-(4-hydroxyphenyl) ethanol, known as tyrosol, which is a phenolic antioxidant found in wine and oil. This compound is produced by soil fungi and has beneficial effects against human diseases, such as cardiovascular disease and thrombosis, and antifungal activity against Lagenidium callinectes and Gibberella pulicaris (Guimarães et al., 2009). Lin et al. (2005) isolated and purified 3 metabolites, including a Diaporthe strain isolated from the rotten leaves of Kandelia candel, a type of mangrove found in Asia, and antimicrobial and cytotoxic activity was observed in the 3 compounds, indicating their potential in biotechnology applications. 
The extract may contain several compounds, and only some may have antimicrobial activity in isolation or in synergistic reactions. The use of chromatographic methods and nuclear magnetic resonance analysis is important for compound identification. Similar screening methods using crude extract can provide initial information regarding antimicrobial, cytotoxic, antioxidant, antimutagenic, and insecticidal activities and identify hormones involved in growth and/or plant defense mechanisms.

\section{CONCLUSIONS}

The endophytic fungi isolated from M. glomerata showed promising results in the in vitro biological control of plant pathogens, and the G-01, G-02, and G-03 strains (molecularly identified as $D$. citri) were the most promising.

The metabolic extracts of G-01 strains showed antibacterial activity against $S$. aureus. Therefore, additional studies are needed to identify the composition and potential of crude extracts. Our results indicate the biotechnological potential of using foliar endophytic fungi of M. glomerata for controlling plant and human pathogens.

\section{REFERENCES}

Aly AH, Edrada-Ebel R, Wray V, Müller WE, et al. (2008). Bioactive metabolites from the endophytic fungus Ampelomyces sp. isolated from the medicinal plant Urospermum picroides. Phytochemistry 69: 1716-1725.

Araújo WL, Lacava PT, Marcon J, Lima AOS, et al. (2010). Guia prático: isolamento e caracterização de microrganismos endofíticos. CALQ, Piracicaba.

Azevedo JL, Macchroni W Jr, Pereira JO and de Araújo WL (2000). Endophytic microrganisms: a review on insect control and recent advances on tropical plants. Electron. J. Biotechnol. 3: 40-65.

Badalyan SM, Innocenti G and Garibyan NG (2002). Antagonistic activity of xylotrophic mushrooms against pathogenic fungi of cereals in dual culture. Phytopathol. Mediterr. 41: 200-225.

Bernardi-Wenzel J, García A, Rubin-Filho CJ, Prioli AJ, et al. (2010). Evaluation of foliar fungal endophytes diversity and colonization of medicinal plant Luehea divaricata (Martiuset et Zuccarini). Biol. Res. 43: 375-384.

Bernardi-Wenzel J, Siqueira AL, Burin FAG, Hein DPR, et al. (2012). Isolamento e atividade antagonística de fungos endofíticos de soja (Glycine max (L.) Merril). Rev. Saúde Biol. 7: 86-96.

Campanile G, Ruscelli A and Luisi N (2007). Antagonistic activity of endophytic fungi towards Diplodia corticola assessed by in vitro and in planta test. Eur. J. Plant Pathol. 117: 237-246.

Dolatabadi HK, Goltapeh EM, Mohammadi N, Rabiey M, et al. (2012). Biocontrol potential of root endophytic fungi and Trichoderma species against Fusarium wilt of lentil under in vitro and greenhouse conditions. J. Agric. Sci. Technol. 14: $407-420$

Ethur LZ, Blume E, Muniz MFB and Flores MGV (2007). Seleção de antagonistas fúngicos a Fusarium solani e Fusarium oxysporum em substrato comercial para mudas. Cienc Rural. 37: 1801-1804.

Falcão HS, Lima IO, Santos VL, Dantas HF, et al. (2005). Review of the plants with anti-inflammatory activity studied in Brazil. Rev. Bras. Farmacogn. 15: 381-391.

Ferreira DF (2011). Sisvar: a computer analysis system. Cienc. Agrotec. 35: 1039-1042.

Fierro IM, da Silva AC, Lopes Cda S, de Moura RS, et al. (1999). Studies on the anti-allergic activity of Mikania glomerata. J. Ethnopharmacol. 66: 19-24.

Garcia A, Rhoden SA, Rubin-Filho CJ, Nakamura CV, et al. (2012a). Diversity of foliar endophytic fungi from medicinal plant Sapindus saponaria L. and their localization by scanning electron microscopy. Biol. Res. 45: 149-158.

Garcia A, Rhoden SA, Bernardi-Wenzel J, Orlandelli RC, et al. (2012b). Antimicrobial activity of crude extracts of endophytic fungi isolated from medicinal plant Sapindus saponaria L. J. App. Pharm. Sci. 2: 35-40.

Gasparetto JC, Campos FR, Budel JM and Pontarolo R (2010). Mikania glomerata Spreng. e M. laevigata Sch. Bip. ex Baker, Asteraceae: estudos agronômicos, genéticos, morfoanatômicos, químicos, farmacológicos, toxicológicos e uso nos programas de fitoterapia do Brasil. Rev. Bras. Farmacogn. 20: 627-640.

Guimarães DO, Borges KB, Bonato OS and Pupo MT (2009). A simple method for the quantitative analysis of Tyrosol by HPLC in liquid Czapek cultures from endophytic fungi. J. Braz. Chem. Soc. 20: 188-194. 
Kimati H, Amorin L, Bergamin Filho A, Camargo LEA, et al. (1997). Manual de Fitopatologia. Vol. 2. Doenças das Plantas Cultivadas. Editora Agronômica Ceres Ltda., São Paulo.

Kusari P, Kusari S, Spiteller M and Kayser O (2013). Endophytic fungi harbored in Cannabis sativa L.: diversity and potencial as biocontrol agents against host plant-specific phytopatogens. Fungal Divers. 60: 137-151.

Lacava PT, Sebastianes FLS and Azevedo JL (2010). Fungos, uma introdução a biologia, bioquímica e biotecnologia. In: Fungos endofíticos: biodiversidades e aplicações biotecnológicas. 2nd edn. (Esposito E and Azevedo JL, eds.). Revisada e ampliada. EDUCS, Caxias do Sul, 533-569.

Lin X, Huang Y, Fang M, Wang J, et al. (2005). Cytotoxic and antimicrobial metabolites from marine lignicolous fungi, Diaporthe sp. FEMS Microbiol. Lett. 251: 53-58.

Mejía LC, Rojas EI, Maynard Z, Bael SV, et al. (2008). Endophytic fungi as biocontrol agents of Theobroma cacao pathogens. Biol. Control 46: 4-14.

Núñez-Trujillo G, Cabrera R, Burgos-Reyes RL, Da Silva E, et al. (2012). Endophytic fungi from Vitis vinifera L. isolated in Canary Islands and Azores as potencial biocontrol agents of Botrytis cinerea Pers.: Fr. J. Hortic. Sci. Biotechnol. 16: 1-6.

Orlandelli RC, Alberto RN, Rubin Filho CJ and Pamphile JA (2012). Diversity of endophytic fungal community associated with Piper hispidum (Piperaceae) leaves. Genet. Mol. Res. 11: 1575-1585.

Pamphile JA and Azevedo JL (2002). Molecular characterization of endophytic strains of Fusarium verticillioides (Fusarium moniliforme) from maize (Zea mays L). Word J. Microbiol. Biotechnol. 18: 391-396.

Pessini GL, Holetz FB, Sanches NR, Cortez DAG, et al. (2003). Avaliação da atividade antibacteriana e antifúngica de extratos de plantas utilizados na medicina popular. Rev. Bras. Farmacogn. 13: 21-24.

Rhoden SA, Garcia A, Azevedo JL and Pamphile JA (2013). In silico analysis of diverse endophytic fungi by using ITS15,8S-ITS2 sequences with isolates from various plant families in Brazil. Genet. Mol. Res. 12: 935-950.

Rukachaisirikul V, Sommart U, Phongpaichit S, Sakayaroj J, et al. (2008). Metabolites from the endophytic fungus Phomopsis sp. PSU-D15. Phytochemistry 69: 783-787.

Ruppelt BM, Pereira EF, Gonçalves LC and Pereira NA (1991). Pharmacological screening of plants recommended by folk medicine as anti-snake venon. I. Analgesic and anti-inflammatory activity. Mem. Inst. Oswaldo Cruz 86: 203-205.

Saitou N and Nei M (1987). The neighbor-joining method: a new method for reconstructing phylogenetic trees. Mol. Biol. Evol. 4: 406-425.

Salgado HRN, Roncari AFF and Moreira RRD (2005). Antidiarrhoeal effects of Mikania glomerata Spreng. (Asteraceae) leaf extract in mice. Rev. Bras. Farmacogn. 15: 205-208.

Schulz B and Boyle C (2005). The endophytic continuum. Mycol. Res. 109: 661-686.

Schulz B, Boyle C, Draeger S, Rommert AK, et al. (2002). Endophytic fungi: a source of novel biologically active secondary metabolites. Mycol. Res. 106: 996-1004.

Silva GH, Teles HL, Zanardi LM, Marx Young MC, et al. (2006). Cadinane sesquiterpenoids of Phomopsis cassiae, an endophytic fungus associated with Cassia spectabilis (Leguminosae). Phytochemistry 67: 1964-1969.

Specian V, Serragiotto MH, Pamphile JA and Clemente E (2012). Chemical characterization of bioactive compounds from endophytic fungus Diaporthe helianthi isolated from Luehea divaricate. Braz. J. Microbiol. 43: 1174-1182.

Stierle A, Strobel GA and Stierle D (1993). Taxol and taxane production by Taxomyces andreanae. Science 260: 214-216.

Stinson M, Ezra D, WM Hess, Sears J, et al. (2003). An endophytic Gliocladium sp. of Eucryphia cordifolia producing selective volatile antimicrobial compounds. Plant Sci. 165: 913-922.

Strobel GA, Miller RV, Martinez-Miller C, Condron MM, et al. (1999). Cryptocandin a potent and antimycotic from the endophytic fungus Cryptosporiopsis cf. quercina. Microbiology 145: 1919-1926.

Vicentino ARR and Menezes FS (2007). Atividade antioxidante de tinturas vegetais, vendidas em farmácias com manipulação e indicadas para diversos tipos de doenças pela metodologia do DPPH. Rev. Bras. Farmacogn. 17: 384-387.

White TJ, Bruns TD, Lee S and Taylor JW (1990). PCR Protocols: A Guide to Methods and Applications. In: Amplification and Direct Sequencing of Fungal Ribosomal RNA Genes for Phylogenetics (Innis MA, Gelfand DH, Sninsky JJ and White TJ, eds.). Academic Press, San Diego, 315-322.

Yu H, Zhang L, Li L, Zheng C, et al. (2009). Recent developments and future prospects of antimicrobial metabolites produced by endophytes. Microbiol. Res. 165: 437-449. 